високим рівнем антропогенного забруднення середовища перебування людини та її життєдіяль-

\section{CANCER RISK ASSESSMENT FOR THE POPULATION OF THE INDUSTRIAL CITIES OF UKRAINE}

Chernychenko I.O., Lytvychenko O.M., Sovertkova L.S., Tsymbaliuk S.M.
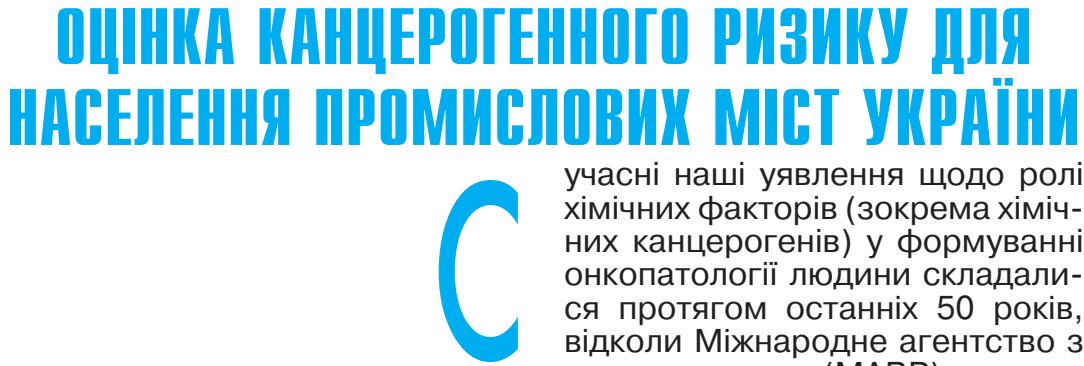

ЧЕРНИЧЕНКО І.О., ЛИТВИЧЕНКО О.М., СОВЕРТКОВА Л.С,.

*ЦИМБАЛЮК С.М.

ДУ „Інститут громадського здоров'я ім. О.М. Марзєєва НАМН України",

*Київський міський ендокринологічний центр МОЗ України

удк 616.006:614.7:615.277.4

Ключові слова: канцерогени, атмосферне повітря, канцерогенний ризик, неканцерогенний ризик, онкологічна захворюваність. учасні наші уявлення щодо ролі хімічних факторів (зокрема хімічних канцерогенів) у формуванні онкопатології людини складалися протягом останніх 50 років, відколи Міжнародне агентство з вивчення раку (МАBР) вперше експертів, близько 3/4 пухлин зумовлене їхнім впливом. Відтоді ця оцінка, незважаючи на численні дані про канцерогени, їх поширеність у навколишньому середовищі, ступінь небезпеки тощо, змінилася мало: ймовірний внесок їх у формування онкозахворювань сягав понад 75\% у 70-ті роки минулого століття, до $80 \%$ - протягом останнього десятиріччя [1].

Тобто особливості рівнів, структури та динаміки захворюваності населення відбивають багатокомпонентний вплив різноманітного спектра етіологічних факторів. Це особливо актуальне для промислових міст 3 дало таку оцінку: за висновками ності. При цьому критеріями екологічного благополуччя $€$ якість життя людини і рівень її здоров'я. Проте екологічна діагностика згаданої онкопатології серед населення певного регіону являє значні труднощі через універсальність механізму розвитку і характеру реакцій відповіді організму на вплив різних шкідливих факторів. Однак шляхом застосування методології оцінки ризику можна виявити кількісний внесок забруднення атмосферного повітря канцерогенними речовинами у рівень захворюваності населення на онкологічні хвороби.

Метою роботи була порівняльна оцінка ролі забруднення канцерогенними сполуками атмосферного повітря ряду промислових міст України у розвитку онкологічних захворювань населення.

Матеріали та методи досліджень. При виборі міст для проведення досліджень і аналізу стану хімічного забруднення повітряного середовища виходили з передумов того, що рівень забруднення атмосфери цими сполуками і характер поширення їх територією населених місць може залежати від багатьох факторів: особливостей планування і забудови, профілю промислового виробництва, ступеня теплофікації,
ОЦЕНКА КАНЦЕРОГЕННОГО РИСКА ДЛЯ НАСЕЛЕНИЯ ПРОМЫШЛЕННЫХ ГОРОДОВ УКРАИНЫ

Черниченко И.А., Литвиченко О.Н., Соверткова Л.С., *Цимбалюк С.Н. ГУ «Институт общественного здоровья им. А.Н. Марзеева НАМН Украины», Г. Киев * Киевский городской эндокринологический центр МОЗ Украины

Целью работы была сравнительная оценка роли загрязнения канцерогенными соединениями атмосферного воздуха ряда промышленных городов Украины в развитии онкологических заболеваний населения.

Материалы и методы исследований. Исследования проведены в 3-х городах Украины с различными уровнями промышленного развития - Киеве, Черкассах, Кременчуге. В атмосферном воздухе исследовали 8 канцерогенных соединений: бенз/а/пирен, летучие N-нитрозамины (N-нитрозодиметиламин и N-нитрозодиэтиламин), формальдегид и тяжелые металлы (кадмий, никель, свинец, хром VI). Для оценки опасности влияния этих веществ и их вклада в формирование онкологической заболеваемости населения городов использовали методологию оценки риска. Информационную базу данных формировали с помощью компьютерной программы Microsoft Excel и пакета прикладных программ.

Результаты и их обсуждение. Анализ данных мониторинга воздушной среды городов (за почти 20-летний период) показал стабильное ее загрязнение исследуемыми веществами и вариабельность. Оценка качества воздуха городов по сум- марным показателям загрязнения показала, что за исследуемый период они незначительно превышали допустимый уровень суммарного загрязнения этими соединениями.

В то же время индексы опасности (неканцерогенный риск) свидетельствуют, что даже такое превышение представляет угрозу для здоровья населения. По величине этих показателей выделен ряд соединений, оказывающих наиболее негативное влияние. Установлено, что суммарный канцерогенный риск влияния этих веществ на население городов, согласно классификации US EPA, оценивается как высокий $\left(>10^{-3}\right)$.

Рассчитанный на этой основе популяционный риск показал, что влияние этих 8 канцерогенов может обусловить появление 2-3 новых случаев рака ежегодно.

Выводы. Результаты многолетних мониторинговых исследований показали стабильное загрязнение атмосферы ряда городов Украины канцерогенными соединениями (8 веществ). Рассчитан неканцерогенный риск выявленного загрязнения. По величине этого показателя выделен ряд соединений, наиболее негативно влияющих на здоровье населения исследуемых городов. Суммарный канцерогенный риск загрязненного этими веществами атмосферного воздуха городов классифицируется как высокий, обусловливающий появление 2-3 новых случаев онкологических заболеваний ежегодно.

Ключевые слова: канцерогенные вещества, атмосферный воздух, канцерогенный риск, неканцерогенный риск, онкологическая заболеваемость. 
автомобілізації тощо. Це зумовило вибір для досліджень населених пунктів з максимально вираженим градієнтом забруднення повітряного середовища цими речовинами: місто Київ та промислові центри 3 переважно специфічними галузями промисловості Кременчук і Черкаси.

В атмосферному повітрі міст досліджували 8 канцерогенних сполук: бенз/а/пірен, леткі $\mathrm{N}$ нітрозаміни (N-нітрозодиметиламін і N-нітрозодіетиламін) - за результатами власних моніто-

\section{Середньорічні концентрації канцерогенних сполук в атмосферному повітрі міст}

\begin{tabular}{|c|c|c|c|c|c|c|c|c|}
\hline \multirow{2}{*}{$\begin{array}{c}\text { Рік спо- } \\
\text { стере- } \\
\text { жень }\end{array}$} & \multicolumn{8}{|c|}{ Концентрація канцерогенів } \\
\hline & 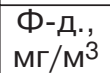 & $\begin{array}{c}\text { БП , } \\
\mathrm{MKг} / \mathrm{M}^{3}\end{array}$ & $\begin{array}{l}\text { НДМА, } \\
\text { Мкг/м³ }\end{array}$ & $\begin{array}{l}\text { НДЕА, } \\
\text { МКг/м³ }\end{array}$ & $\begin{array}{l}\text { Кадмій, } \\
\text { мкг/м³ }\end{array}$ & $\begin{array}{l}\text { Нікель, } \\
\text { мкг/м³ }\end{array}$ & 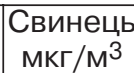 & 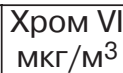 \\
\hline \multicolumn{9}{|c|}{ м. Київ } \\
\hline 1997 & 0,0033 & 0,0034 & 0,0402 & 0,012 & 0,137 & 0,233 & 0,270 & 0,021 \\
\hline 1998 & 0,0040 & 0,0029 & 0,0483 & 0,014 & 0,165 & 0,280 & 0,334 & 0,025 \\
\hline 1999 & 0,0034 & 0,0025 & 0,0416 & 0,012 & 0,142 & 0,241 & 0,287 & 0,017 \\
\hline 2000 & 0,0039 & 0,0028 & 0,0469 & 0,013 & 0,160 & 0,272 & 0,324 & 0,024 \\
\hline 2001 & 0,0034 & 0,0024 & 0,0411 & 0,012 & 0,140 & 0,238 & 0,284 & 0,018 \\
\hline 2002 & 0,0038 & 0,0032 & 0,0501 & 0,015 & 0,168 & 0,260 & 0,310 & 0,026 \\
\hline 2003 & 0,0044 & 0,0033 & 0,0445 & 0,016 & 0,167 & 0,316 & 0,367 & 0,030 \\
\hline 2004 & 0,0033 & 0,0024 & 0,0387 & 0,011 & 0,136 & 0,230 & 0,274 & 0,020 \\
\hline 2005 & 0,0031 & 0,0023 & 0,0378 & 0,011 & 0,129 & 0,219 & 0,261 & 0,019 \\
\hline 2006 & 0,0029 & 0,0020 & 0,0349 & 0,010 & 0,119 & 0,202 & 0,241 & 0,017 \\
\hline 2007 & 0,0036 & 0,0026 & 0,0430 & 0,012 & 0,147 & 0,250 & 0,298 & 0,018 \\
\hline 2008 & 0,0041 & 0,0030 & 0,0497 & 0,014 & 0,170 & 0,289 & 0,344 & 0,029 \\
\hline 2009 & 0,0032 & 0,0026 & 0,0415 & 0,011 & 0,140 & 0,225 & 0,250 & 0,014 \\
\hline 2010 & 0,0034 & 0,0025 & 0,0370 & 0,012 & 0,142 & 0,241 & 0,288 & 0,020 \\
\hline 2011 & 0,0037 & 0,0027 & 0,0445 & 0,013 & 0,152 & 0,258 & 0,298 & 0,023 \\
\hline 2012 & 0,0033 & 0,0024 & 0,0406 & 0,012 & 0,139 & 0,236 & 0,281 & 0,021 \\
\hline 2013 & 0,0039 & 0,0032 & 0,0440 & 0,013 & 0,172 & 0,310 & 0,290 & 0,024 \\
\hline \multicolumn{9}{|c|}{ м.Черкаси } \\
\hline 1997 & 0,010 & 0,0011 & 0,0480 & 0,0132 & 0,02 & 0,04 & 0,07 & 0,05 \\
\hline 1998 & 0,012 & 0,0013 & 0,0424 & 0,0192 & 0,03 & 0,05 & 0,09 & 0,07 \\
\hline 1999 & 0,009 & 0,0014 & 0,0240 & 0,0153 & 0,01 & 0,02 & 0,04 & 0,04 \\
\hline 2000 & 0,012 & 0,0012 & 0,0440 & 0,0140 & 0,03 & 0,05 & 0,07 & 0,04 \\
\hline 2001 & 0,011 & 0,0013 & 0,0439 & 0,0121 & 0,02 & 0,05 & 0,05 & 0,04 \\
\hline 2002 & 0,011 & 0,0016 & 0,0525 & 0,0144 & $0,0<$ & 0,04 & 0,05 & 0,05 \\
\hline 2003 & 0,011 & 0,0017 & 0,0533 & 0,0124 & 2 & 0,00 & 4 & 0,04 \\
\hline 2004 & 0,011 & 0,0018 & 0,0499 & 0,0123 & 0,03 & U & 0,05 & 0,05 \\
\hline 2005 & 0,009 & 0,0020 & 0,0442 & 0,0122 & 0,02 & U & 4 & 0,03 \\
\hline 2006 & 0,008 & 0,0015 & 0529 & 0,0139 & 0,03 & 0,05 & 0,03 & 0,03 \\
\hline 2007 & 0,010 & 0,0014 & 0,0550 & 0,0132 & 3 & 0,07 & 0,02 & 0,05 \\
\hline 2008 & 0,009 & 0,0023 & 0530 & 0,0141 & 0,02 & 0,04 & 0,05 &, 05 \\
\hline 2009 & 0,009 & 0,0022 & 0,0501 & 0,0135 & 0,02 & 0,05 & 0,04 & 0,04 \\
\hline 2010 & 0,011 & 0,0019 & 0,0441 & 0,0140 & 0,02 & 0,04 & 0,04 & 0,04 \\
\hline 2011 & 0,012 & 0,0018 & 0,0500 & 0,0151 & 0,03 & 0,06 & 0,06 & 0,05 \\
\hline 2012 & 0,011 & 0,0022 & 0,0480 & 0,0160 & 0,03 & 0,07 & 0,05 & 0,04 \\
\hline 2013 & 0,012 & 0,0023 & 0,0515 & 0,0165 & 0,02 & 0,07 &, 04 & 0,04 \\
\hline
\end{tabular}

Результати та їх обговорення. Аналіз даних моніторингу повітряного середовища міст (за майже 20-річний період) свідчить про стабільне його забруднення досліджуваними канцерогенами та його варіабельність (табл. 1)

Якщо оцінити рівні забруднення атмосфери м. Києва протягом усього періоду досліджень, можна відзначити, що концентрації окремих сполук (НА, ВМ, за винятком свинцю) не перевищували встановлених гігієнічних нормативів; концентрації БП у 100\% проб перевищували ГДК у 2,3-3,3 рази, формальдегіду - майже у $100 \%$ проб в 1,1-1,5 рази, свинцю - у $30 \%$ проб в 1,1 рази.

Щодо міста Черкаси, то рівень забруднення атмосфери цими сполуками там дещо інший: концентрації БП та формальдегіду у $100 \%$ проб перевищували гранично допустимі рівні в 1,1-2,3 та 3,0-4,0 рази відповідно, концентрації НА (НДМА та НДЕА) виявлялися практично на рівні ГДК, рівні вмісту ВМ не перевищували допустимих за весь період спостережень.

У Кременчуці також спостерігається перевищення гранично допустимих концентрацій таких речовин, як БП та формальдегід у $100 \%$ проб (в 1,1-2,7 та 2,7-4 рази відповідно); концентрації НА (НДМА та НДЕА) визначалися майже на рівні ГДК, рівні вмісту ВM не перевищували допустимих за увесь період спостережень.

Якщо оцінювати якість атмосферного повітря міст за сумарними показниками забруднення (співвідношення реальних концентрацій сполук та їхніх ГДК з урахуванням класу небезпеки речовини) [3], можна відзначити, що вони також відрізняються, і це дає змогу за показником забруднення виявити сполуки, які роблять найбільший внесок у загальне забруднення повітряного середовища міста.

Розраховані величини показників порівнювали 3 сумарним показником забруднення, отриманим за умов дотримання гігієнічних нормативів для усіх сполук, за якими велося спостереження. У наших дослідженнях обрано 8 речовин. Зважаючи на відповідні санітарні правила [3], цей критеріальний показник має дорівнювати 9,9.

Аналіз за цим критерієм реальної ситуації за досліджуваний період показав, що, за винятком декількох років, забруднення повітряного середовища досліджуваних міст практично не перевищувало допустимий рівень сумарного забруднення цими 


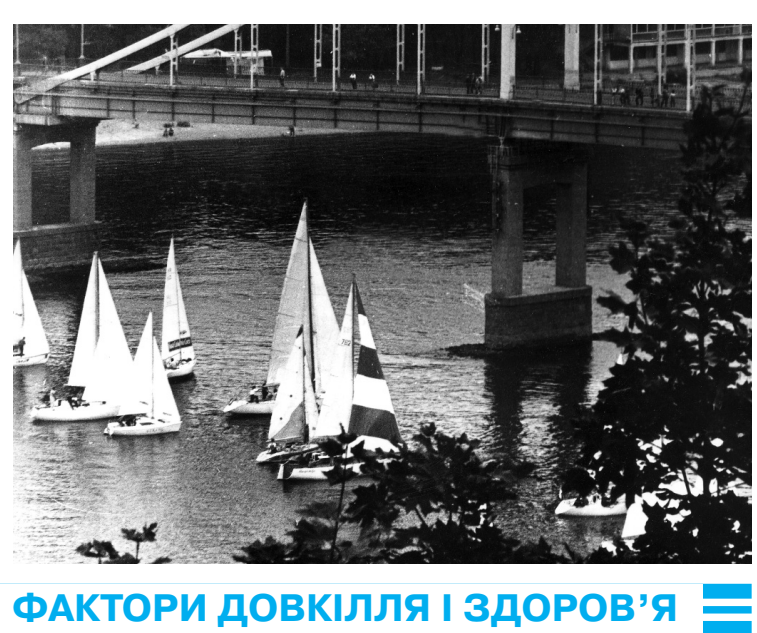

сполуками.

Однак ці показники характеризують саме ступінь хімічного забруднення повітряного середовища міст, і за величинами показників неможливо оцінити небезпеку такого забруднення для здоров'я населення цих міст. Для оцінки небезпеки розраховували неканцерогенний та канцерогенний ризики, які дають змогу кількісно оцінити шкідливий вплив, що створюється цими сполуками, виявити, які 3 них найбільш негативно впливають на здоров'я мешканців міст визначають напрямок епідеміологічних досліджень.

Кількісну оцінку неканцерогенного ризику для здоров'я населення досліджуваних міст від забруднення атмосферного повітря хімічними сполуками проводили шляхом розрахунку коефіцієнтів неканцерогенної небезпеки окремо для усіх хімічних речовин для кожного міста і кожного року спостережень та розрахунку сумарних індексів неканцерогенної небезпеки для сукупності речовин [2].

Аналіз розрахунків дозволив виділити ті з досліджуваних сполук, які справляють на здоров'я населення міст найбільший негативний вплив як токсиканти. Для міста Київ - це кадмій, нікель, БП, для Черкас - формальдегід, БП, для Кременчука - формальдегід, БП та бензол. Під шкідливий вплив цих канцерогенів насамперед підпадають, як відомо, органи дихання, імунна система та гормональний статус людини [2]. Це призводить до пошкодження нормального їх функціонування і підвищення рівня первинної захворюваності цих органів і систем. Це було показано нами раніше при аналізі показників захворюваності населення [4, 5].

Слід зазначити, що критерії оцінки неканцерогенного ризику менш інформативні, ніж канцерогенного, вони дають змогу лише порівнювати і за коефіцієнтом небезпеки ранжувати сполуки для обґрунтування профілактичних заходів щодо зменшення викиду їх у повітряне середовище.

Насправді ризик неканцерогенного ефекту не відповідає традиційному поняттю про ризик як ймовірність появи шкідливого ефекту, тобто коефіцієнт та індекс небезпеки не можуть бути інтерпретованими з точки зору кількості можливих захворювань, і це не дає змоги отримати уяву щодо величини захворюваності за різних рівнів впливу сполуки.

щодо канцерогенних ефектів, то в експериментах та клінічноепідеміологічних дослідженнях, результати яких застосовуються у методології оцінок ризику, вони встановлюються за даними наявності чи відсутності відповідних порушень у здоров'ї кожної окремої людини у досліджуваних групах, i це дозволяє визначати частку індивідуумів 3 даними порушеннями і таким чином оцінювати їхню ймовірність. Водночас неканцерогенні ефекти при нелітальних рівнях впливу встановлюються за змінами середньогрупових, а не індивідуальних значень показників стану органів та систем організму.

US EPA [6] запропоновано класифікацію рівнів ризику для здоров'я людини, яка більш конкретно відображає систему градацій неканцерогенного (за показниками коефіцієнта та індексу небезпеки) і канцерогенного ризику, зменшує невизначеності при оцінці сумарного неканцерогенного ризику сполук

односпрямованої дії (табл. 2).

За рекомендаціями US EPA [6], за високого рівня ризику необхідне проведення термінових оздоровчих та інших заходів щодо його зниження. За насторожуючого рівня ризику необхідний постійний контроль, розробка і проведення планових оздоровчих заходів. За допустимого рівня ризику здійснюється постійний контроль над цими сполуками, передбачається планування і проведення додаткових заходів щодо його зниження. Мінімальний (цільовий) рівень ризику не потребує заходів з його зниження. Ці рівні підлягають періодичному контролю 3 метою підтримання якості даного об'єкта середовища проживання людини на сприятливому рівні.

Аналіз за цими критеріями коефіцієнтів та індексів небезпеки показав наступне. У Києві рівні неканцерогенного ризику від

Таблиця 1 (закінчення)

Середньорічні концентрації канцерогенних сполук в атмосферному повітрі міст

\begin{tabular}{|c|c|c|c|c|c|c|c|c|}
\hline \multirow{2}{*}{\begin{tabular}{|c|} 
Рік спо- \\
стере- \\
жень
\end{tabular}} & \multicolumn{8}{|c|}{ Концентрація канцерогенів } \\
\hline & 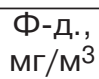 & $\begin{array}{c}\text { БП , } \\
\text { мКг } / \mathrm{M}^{3}\end{array}$ & $\begin{array}{l}\text { НДМА, } \\
\text { МКГ } / \mathrm{M}^{3}\end{array}$ & $\begin{array}{l}\text { НДЕА, } \\
\text { МКГ/M }{ }^{3}\end{array}$ & $\begin{array}{l}\text { Кадмій } \\
\text { мкг/м³ }\end{array}$ & $\begin{array}{l}\text { Нікель, } \\
\text { мкг } / \mathrm{M}^{3}\end{array}$ & $\begin{array}{c}\text { Свинець } \\
\text { мкг/M }{ }^{3}\end{array}$ & 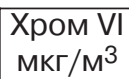 \\
\hline \multicolumn{9}{|c|}{ м.Кременчук } \\
\hline 1997 & 0,012 & 0,0027 & 0,0491 & 0,0153 & 0,03 & 0,04 & 0,07 & 0,05 \\
\hline 1998 & 0,010 & 0,0019 & 0,0478 & 0,0172 & 0,02 & 0,05 & 0,08 & 0,07 \\
\hline 1999 & 0,010 & 0,0014 & 0,0441 & 0,0162 & 0,02 & 0,05 & 0,07 & 0,05 \\
\hline 2000 & 0,010 & 0,0015 & 0,0489 & 0,0147 & 0,03 & 0,03 & 0,06 & 0,05 \\
\hline 2001 & 0,009 & 0,0011 & 0,0531 & 0,0158 & 0,02 & 0,04 & 0,06 & 0,04 \\
\hline 2002 & 0,010 & 0,0013 & 0,0518 & 0,0149 & 0,01 & 0,05 & 0,08 & 0,05 \\
\hline 2003 & 0,011 & 0,0014 & 0,0544 & 0,0153 & 0,02 & 0,04 & 0,07 & 0,05 \\
\hline 2004 & 0,010 & 0,0016 & 0,0528 & 0,0158 & 0,01 & 0,05 & 0,08 & 0,06 \\
\hline 2005 & 0,009 & 0,0014 & 0,0539 & 0,0146 & 0,01 & 0,03 & 0,08 & 0,04 \\
\hline 2006 & 0,008 & 0,0012 & 0,0558 & 0,0151 & 0,02 & 0,03 & 0,00 & 0,04 \\
\hline 2007 & 0,009 & 0,0016 & 0,0571 & 0,0148 & 0,01 & 0,04 & 0,00 & 0,05 \\
\hline 2008 & 0,008 & 0,0015 & 0,0569 & 0,0152 & 0,03 & 0,06 & 0,07 & 0,05 \\
\hline 2009 & 0,009 & 0,0017 & 0,0558 & 0,0159 & 0,02 & 0,05 & 0,07 & 0,04 \\
\hline 2010 & 0,010 & 0,0019 & 0,0566 & 0,0152 & 0,03 & 0,06 & 0,08 & 0,05 \\
\hline 2011 & 0,011 & 0,0018 & 0,0559 & 0,0161 & 0,02 & 0,04 & 0,07 & 0,05 \\
\hline 2012 & 0,012 & 0,0020 & 0,0571 & 0,0165 & 0,03 & 0,07 & 0,09 & 0,06 \\
\hline 2013 & 0,010 & 0,0019 & 0,0584 & 0,0167 & 0,02 & 0,06 & 0,07 & 0,06 \\
\hline
\end{tabular}



лю) можна оцінити як високі, від БП, формальдегіду - насторожуючі, від НДМА, НДЕА, свинцю та хрому - допустимі. Рівні неканцерогенного ризику для сполук односпрямованої дії оцінюються як високі для важких металів, насторожуючі - для сполук НДМА+НДЕА.

У м. Черкаси рівень неканцерогенного ризику формальдегіду класифікується як високий, БП та кадмію - насторожуючий, для решти сполук - допустимий; для сполук односпрямованої дії рівні неканцерогенного ризику оцінюються як насторожуючі.

Для Кременчука за увесь період спостережень рівні неканцерогенного ризику визначаються як насторожуючі, за винятком формальдегіду (високий), свинцю і хрому шестивалентного (допустимий).

Така градація рівнів неканцерогенного ризику дає змогу обґрунтувати проведення відповідних заходів з його мінімізації як для окремих сполук, так і

\section{Класифікація рівнів ризику}

\begin{tabular}{|l|c|c|c|}
\hline Рівень ризику & $\begin{array}{c}\text { Коефіцієнт } \\
\text { небезпеки } \\
\text { розвитку некан- } \\
\text { церогенних } \\
\text { ефектів (НQ) } \\
\text { для окремих } \\
\text { сполук }\end{array}$ & $\begin{array}{c}\text { Індекс небезпеки } \\
\text { розвитку } \\
\text { ефектів (НІ) } \\
\text { для групи } \\
\text { сполук одно- } \\
\text { спрямованої дії }\end{array}$ & $\begin{array}{c}\text { Індивідуальний } \\
\text { канцерогенний } \\
\text { ризик } \\
\text { жротям } \\
\text { життя }\end{array}$ \\
\hline Високий & $>3$ & $>6$ & $>10^{-3}$ \\
\hline Насторожуючий & $1,1-3$ & $3,1-6$ & $1,1 \times 10^{-4}-1,0 \times 10^{-3}$ \\
\hline Допустимий & $0,11-1,0$ & $1,1-3,0$ & $1,1 \times 10^{-6}-1,0 \times 10^{-4}$ \\
\hline $\begin{array}{l}\text { Мінімальний } \\
\text { (цільовий) }\end{array}$ & 0,1 і менше & 1,0 і менше & $10^{-6}$ і менше \\
\hline
\end{tabular}

забруднення повітряного середовища міста загалом. видно, що хоча показники забруднення повітряного середовища міст за досліджуваний період незначно перевищують критеріальний показник, сумарні індекси небезпеки (показники неканцерогенного ризику) вкавелике перевищення становить загрозу для здоров'я мешканців цих міст.

Оскільки досліджувані сполуки $€$ канцерогенами, було розраховано канцерогенний ризик їхнього впливу для кількісної оцінки небезпеки для населення, що вітряного середовища міст цими речовинами. Розрахунки проводили за тим же алгоритмом, що і при визначенні неканцерогенного ризику. Оцінку отриманих величин канцерогенного ризику для здоров'я населення проводили 3 огляду на систему критеріїв рівня ризику, рекомендовану US EPA [6] (табл. 2).

Таблиця 2 важких металів (кадмію та ніке-

3 наведених вище даних зують, що навіть таке не дуже створюється забрудненням по-

\section{Канцерогенний ризик повітряного середовища досліджуваних міст}

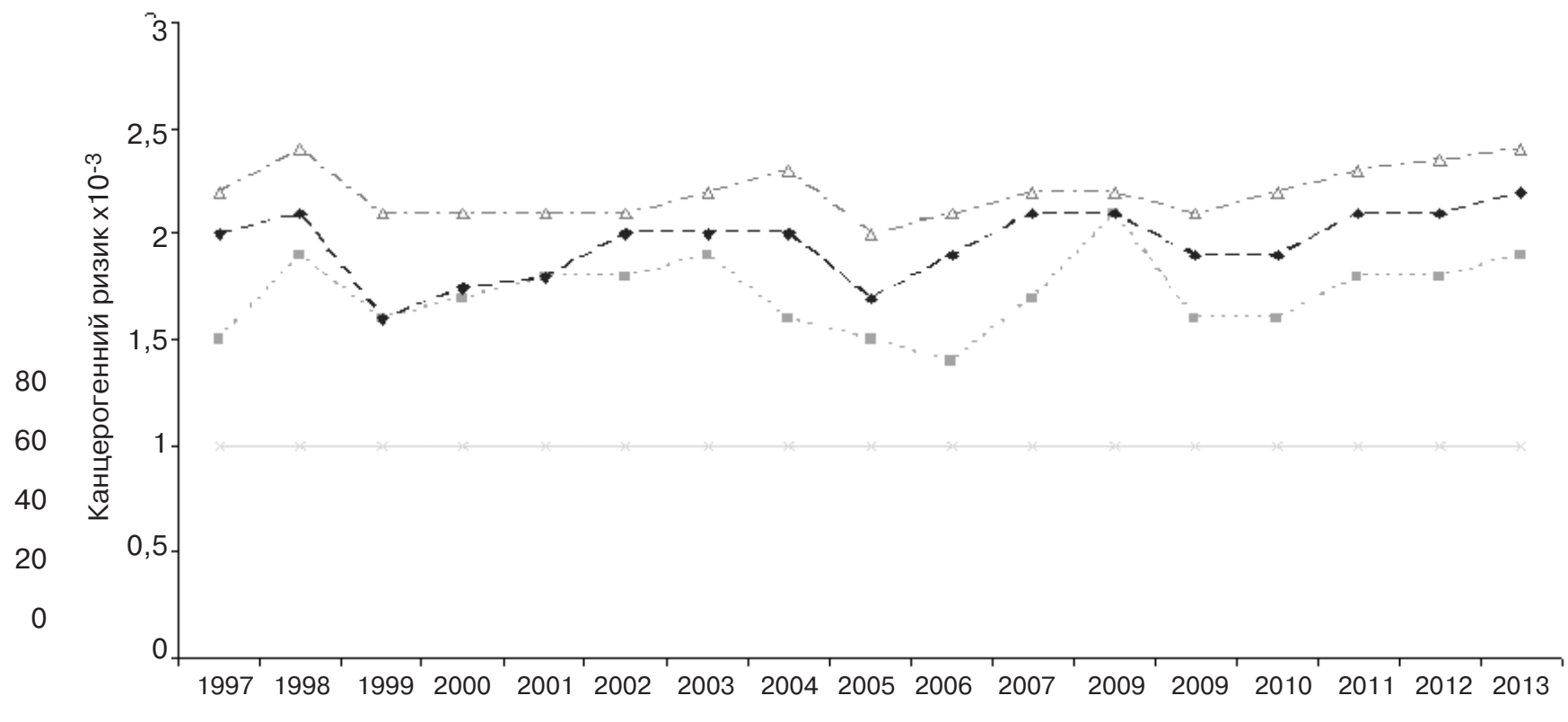

Аналіз результатів (табл. 2) показав, що канцерогенний ризик інгаляційного впливу лише однієї 3 досліджуваних сполук - свинцю практично можна класифікувати як мінімальний. Для нікелю, БП та формальдегіду (у м. Київ) канцерогенний ризик оцінюється як допустимий; для хрому VI, нітрозамінів (НДМА та НДЕА), кадмію, формальдегіду (у м. Черкаси та М. Кременчук) - як насторожуючий. Ці матеріали дозволяють за величиною показника канцерогенного ризику сполук, присутніх у повітряному середовищі міст, провести їх ранжування, встановити найбільш небезпечні у канцерогенному відношенні. Визначення джерел їх надходження у повітря дає змогу з огляду на показник ризику обґрунтувати заходи щодо зменшення їхнього шкідливого навантаження на організм.

Щодо сумарного канцерогенного ризику для здоров'я населення, що створюється досліджуваними сполуками у повітряному середовищі міст, він коливався протягом усього періоду моніторування у межах 1,51,9×10-3 у Києві, $1,6-2,1 \times 10^{-3}$ та $2,0-2,4 \times 10^{-3}$ у Черкасах та Кременчуці відповідно (рис.). Такі рівні, згідно з класифікацією US EPA [6], розглядаються як високі $\left(>10^{-3}\right)$, і це потребує заходів $з$ його зниження. Тобто існуючий рівень забруднення повітряного середовища міст канцерогенними сполуками не може вважатися безпечним для здоров'я його мешканців (і це тільки за вісьмома канцерогенами).

Рисунок

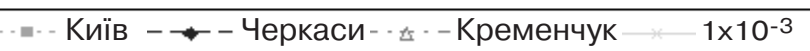


CANCER RISK ASSESSMENT FOR THE POPULATION OF THE INDUSTRIAL CITIES OF UKRAINE

Chernychenko I.O., Lytvychenko O.M., Sovertkova L.S., Tsymbaliuk S.M. SI "O.M. Marzeyev Institute for Public Health, National Academy of Medical Science of Ukraine"

Objective. We performed a comparative assessment of the role of ambient air pollution with carcinogenic compounds in the number of the industrial cities of Ukraine in the development of oncological diseases of the population.

Materials and methods. The research was carried out in 3 cities with different levels of the industrial development - Kyiv, Cherkasy, Kremenchuh. 8 carcinogenic compounds: benz/a/pyrene, volatile $\mathrm{N}$-nitrosamines ( $\mathrm{N}$-nitrozodimethylamine and $\mathrm{N}$-nitrozodiethylamine), formaldehyde and heavy metals (cadmium, nickel, lead, chromium VI) were studied in ambient air. For the assessment of the risk of these substances and their contribution to the formation of population cancer incidence in the cities we used a methodology of risk assessment. The information database was formed with the help of the Microsoft Excel computer program and software package. Results and discussion: Analysis of air monitoring data of the cities (for almost 20-years' period) showed a stable pollution with these substances and its variability.

The air quality assessment in the cities by the total pollution indicators showed their slightly excess of the permissible level of total pollution with those compounds.

At the same time, risk indices (non-carcinogenic risk) indicate that even such an excess poses a threat to public health; by the value of these indicators a number of the compounds, having the most negative influence, were identified.

The total carcinogenic risk of the influence of these substances on the population of the cities was established to be high ( $>10^{-3}$ ) according to the US EPA classification.

The population risk, calculated on this basis, demonstrated that the influence of these 8 carcinogens could cause 2-3 new cancer cases every year.

Conclusions. The results of long-term monitoring studies have shown the stable pollution of the atmosphere with carcinogenic compounds (8 substances) in some Ukrainian cities. The non-carcinogenic risk of the identified pollution was calculated according to the value of this index, a number of the compounds, affecting the most negatively the health of the population of studied cities, was detected. The total carcinogenic risk of the ambient air of the cities, polluted with these substances, is classified as a high one that causes 2-3 new cancer cases every year.

Keywords: carcinogenic substances, ambient air, carcinogenic risk, non-carcinogenic risk, oncological morbidity.
Щоб оцінити небезпеку для населення міст таких рівнів канцерогенного ризику, розраховували популяційний канцерогенний ризик, який характеризує верхню межу можливого канцерогенного ризику протягом періоду, що відповідає середній тривалості життя людини - 70 років [2]. Цей показник розраховували зважаючи на усереднені дані за увесь період спостережень (1997-2013) щодо населення досліджуваних міст [7] та показників сумарного канцерогенного ризику. За показниками популяційного ризику розрахували очікуваний середній річний приріст онкологічної захворюваності населення за впливу цих сполук (табл. 3).

Як видно з таблиці, досліджувані сполуки зумовлюють ризик появи 2-3 нових випадків захворювань на рак щорічно. Якщо врахувати, що на сьогодні експертами МАВР 119 хімічних сполук класифікуються як доведені канцерогени для людини, розширення спектра досліджуваних сполук могло б значно збільшити внесок екологічних факторів як причин розвитку онкологічної захворюваності. На користь цього свідчать результати проведених нами досліджень бензолу в атмосферному повітрі м. Кременчука протягом тривалого періоду. Попередні результати досліджень можливого впливу його на здоров'я мешканців міста показали, що виявлені концентрації сполуки зумовлюють ризик появи 1-2 випадків онкозахворювань на рік на 100 тисяч населення.

Розрахований нами канцерогенний ризик у досліджуваних містах на рівнях, значно вищих за допустимий, підтверджується даними щодо онкологічної захворюваності населення цих міст. За даними Національного Канцер-реєстру України [8], за період моніторування приріст первинної захворюваності на злоякісні новоутворення склав майже $20 \%$.

Таким чином, результати моніторингу якості атмосферного повітря в умовах великих промислових міст показали, що населення протягом тривалого періоду піддається високому ризику розвитку онкологічних захворювань, що підтверджується і фактичними показниками захворювань на цю патологію населення, що проживає на території цих населених пунктів. Це зумовлює необхідність розробки і впровадження у містах спеціальних програм щодо зниження ризику розвитку онкопатології населення.
ЛITЕРATУPA

1. IARC Monographs on the Evaluation of Carcinogenic Risks to Humans. Available at: http://www.monograph.iarc.fr

2. Оцінка ризику для здоров'я населення від забруднення атмосферного повітря: метод. рек. МР 2.2.12-142-2007. Київ : МОЗ України, 2007. 28 с.

3. Державні санітарні правила охорони атмосферного повітря населених місць від забруднення хімічними і біологічними речовинами : ДСП-201-97. Київ : МОЗ України, 1997. 57 с.

4. Малоног К.П., Литвиченко О.М., Бондаренко Ю.Г. Вивчення впливу забруднювачів атмосферного повітря на стан здоров'я населення. Гігієна населених місць: зб. наук. праць. Київ, 2006. Вип. 47. С. 58-63.

5. Черниченко І.О., Литвиченко О.М., Цимбалюк С.М., Швагер О.В., Соверткова Л.С., Баленко Н.В. Хімічні канцерогени атмосферного повітря : вплив на захворюваність населення на

Таблиця 3

Популяційний ризик онкологічних захворювань населення міст за впливу досліджуваних канцерогенних сполук

\begin{tabular}{|l|c|c|c|c|}
\hline Місто & $\begin{array}{c}\text { Чисельність } \\
\text { населення } \\
\text { (середня 3а } \\
\text { увесь період } \\
\text { спостережень), } \\
\text { тис. чол. }\end{array}$ & $\begin{array}{c}\text { Сумцерний } \\
\text { ризик (середний } \\
\text { за увесь період } \\
\text { спостережень), } \\
\text { х10-3 }\end{array}$ & $\begin{array}{c}\text { Популя- } \\
\text { ційний } \\
\text { ризик, } \\
\text { чол. }\end{array}$ & $\begin{array}{c}\text { Річний } \\
\text { приріст } \\
\text { (на 100 } \\
\text { тис. нас.) }\end{array}$ \\
\hline Київ & 2703,375 & 1,7 & 4596 & 2,5 \\
\hline Черкаси & 287,749 & 1,9 & 542 & 2,7 \\
\hline Кременчук & 228,419 & 2,1 & 479 & 2,9 \\
\hline
\end{tabular}


рак щитоподібної залози. Гігієна населених місць: зб. наук. праць. Київ, 2015 . Вип. 66. C. 104-110.

6. Supplementary Guidance for Conducting Health Risk Assessment of Chemical Mixtures. Washington, $2000: 194 \mathrm{p}$

7. Населення міст України. Режим доступу: http://www.ukrmap.org. ua/Naselenie.htm

8. Національний канцер-реєстр. Режим доступу: http://www.ncru.inf.ua REFERENCES

1. IARC Monographs on the Evaluation of Carcinogenic Risks to Humans. Available at: http://www.monograph.iarc.fr

2. Otsinka ryzyku dlia zdorovia naselennia vid zabrudnennia atmosfernoho povitria: metodychni rekomendatsii MR 2.2.12-142-2007 [Assessment of the Risk for the Health of the Population from the Ambient Air Pollution: Methodical Recommendations MR 2.2.12-1422007]. Kyiv : MOZ Ukraini; 2007 : 28 p. (in Ukrainian).

3. Derzhavni sanitarni pravyla okhorony atmosfernoho povitria naselenykh mists vid zabrudnennia khimichnymy i biolohichnymy rechovynamy : DSP-201-97 [State Sanitary Norms on the Protection of Ambient Air of the Settlements from the Contamination of Chemical and Biological Substances: SSR-201-97]. Kyiv : MOZ Ukrainy; 1997 : 57 p. (in Ukrainian).

4. Malonoh K.P., Lytvychenko O.M and Bondarenko Yu.H. Vyvchennia vplyvu zabrudniuvachiv atmosfernoho povitria na stan zdorovia naselennia [Study of the Impact of Ambient Air Pollutants on the Health State of the Population]. In : Hihiena naselenykh mists: zb. nauk. prats [Hygiene of Settlements]. Kyiv ; 2006 ; 47 : 58-63 (in Ukrainian).

5. Chernychenko I.O., Lytvychenko O.M., Tsymbaliuk S.M., Shvaher O.V., Sovertkova L. S. and Balenko N.V. Khimichni kantseroheny atmosfernoho povitria : vplyv na zakhvoriuvanist naselennia na rak shchytopodibnoi zalozy [Chemical Carcinogens of Ambient Air : Impact on the Population's Morbidity of Thyroid Gland Cancer]. In : Hihiena naselenykh mists: zb. nauk. prats [Hygiene of Settlements]. Kyiv ; 2015; 66 : 104-110 (in Ukrainian).

6. Supplementary Guidance for Conducting Health Risk Assessment of Chemical Mixtures. Washington, 2000 : $194 \mathrm{p}$.

7. Naselennia mist Ukrainy [Population of the Cities of Ukraine]. Available at : http://www.ukrmap. org.ua/Naselenie.htm

8. Natsionalnyi kantser-reiestr [National Cancer Register]. Available at : http://www.ncru.inf.ua

Надійшла до редакції 17.12.2016

FOLIC ACID IN THE PROPHYLACTIC MEDICINE

Polka O.O., Omelchenko E.M., Kachko H.O., Pedan L.R. ФОЛЕВА КИСЛОТА

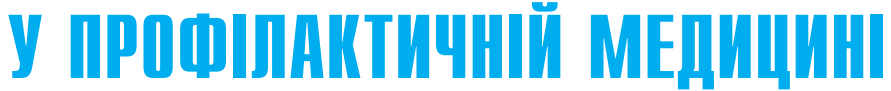

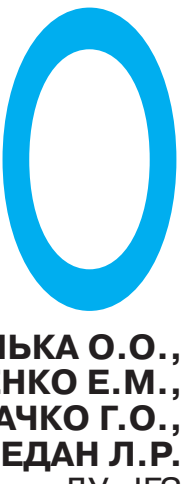

ДУ «ГГЗ

ім. О.М. Марзєєва

НАМНУ», м. Київ

УДК 613.2:577.164.1

Ключові слова: первинна

профілактика, фолієва

кислота, вроджені вади. станнім часом в Україні знову постало питання щодо необхідності фортифікації борошна фолієвою кислотою (вітамін $\mathrm{B}_{9}$ ). Лабораторія епідеміологічних досліджень і медичної інформатики має багаторічні напрацювання у цій сфері, тому вважаємо за доцільне представити бачення проблеми, ґрунтуючись на результатах власних досліджень та літературних джерелах.

Вперше фолієву кислоту виділили із листя (folium) шпинату і встановили хімічний склад П. Мітчелл і співавтори (19411944). До організму вітамін $B_{9}$ надходить переважно у складі таких продуктів харчування, як боби, спаржа, брокколі, шпинат, гриби, дріжджі, петрушка, печінка, м'ясо (табл. 1).

Однак через нестійкість під час кулінарної обробки та погане всмоктування у шлунково-кишковому тракті навіть збалансований раціон харчування забезпечує лише $2 / 3$ добової потреби у фолієвій кислоті, 1/3 синтезує кишкова мікрофлора.

В організмі запаси фолієвої кислоти сконцентровані у нирках і печінці (5-20 г),

ФОЛИЕВАЯ КИСЛОТА В ПРОФИЛАКТИЧЕСКОЙ МЕДИЦИНЕ Полька Е.А., Омельченко Э.М., Качко Г.А., Педан Л.Р. ГУ «ИОЗ НАМНУ им. А.Н. Марзеева»

Цель. Оценить фолирование муки как возможный способ массовой профилактики врожденной патологии.

Материалы и методы: аналитический, библиографический. Результаты. Существуют свидетельства снижения риска возникновения врожденных пороков нервной трубки у детей, рожденных женщинами, которые принимали 800 мкг фолиевой кислоты в преконцепционный период. К развитию недостаточности этого витамина может привести низкое содержание его в пище, дисбактериоз различной этиологии (например, длительный прием сульфаниламидов) и нарушения метаболизма фолиевой кислоты, который меняется при носительстве C677T и A1298С полиморфизмов гена метилентетрагидрофолатредуктазы (MTHFR). Частота носительства MTHFR со сниженной активностью в Украине достаточно высока. На популяционном уровне это приводит к неэффективности ее применения и токсичности, поскольку накопление метаболитов фолиевой кислоты ведет к развитию диспептических явлений, аллергических реакций и дефицита витамина $B_{12}$. Следовательно, ее применение с профилактической целью требует индивидуального подхода к каждому пациенту, особенно при учете возможного носительства аллельных вариантов гена MTHFR. Их распространенность на территории Украины и клиническое значение на сегодня остаются недостаточно исследованными.

Вывод. Считаем целесообразным проведение в Украине масштабных исследований относительно содержания фолатов в пищевом рационе, усвояемости и содержания в плазме крови в различных возрастных группах. Полученные результаты могут быть доказательной базой для решения вопроса о фортификации.

Ключевые слова: первичная профилактика, фолиевая кислота, врожденные пороки.

() Полька О.О., Омельченко Е.М., Качко Г.О., Педан Л.Р. СТАTТЯ, 2017. 